\title{
A mechanism for biogenic production and emission of MEK from MVK decoupled from isoprene biosynthesis
}

\author{
Luca Cappellin ${ }^{1,2}$, Francesco Loreto ${ }^{3,4}$, Franco Biasioli ${ }^{1}$, Paolo Pastore ${ }^{2}$, and Karena McKinney ${ }^{5}$ \\ ${ }^{1}$ Research and Innovation Centre, Fondazione Edmund Mach, S. Michele a/A 38010, Italy \\ ${ }^{2}$ Dipartimento di Scienze Chimiche, Università degli Studi di Padova, Padova, Italy \\ ${ }^{3}$ Consiglio Nazionale delle Ricerche (CNR), Dipartimento di Scienze Bio-Agroalimentari (DISBA), Roma 7-00185, Italy \\ ${ }^{4}$ Dipartimento di Biologia, Università degli Studi di Napoli Federico II, Napoli, Italy \\ ${ }^{5}$ Colby College, Waterville, Maine, USA
}

Correspondence: Luca Cappellin (luca.cappellin@gmail.com)

Received: 13 September 2018 - Discussion started: 14 November 2018

Revised: 7 February 2019 - Accepted: 12 February 2019 - Published: 12 March 2019

\begin{abstract}
Methyl ethyl ketone (MEK) is an important compound in atmospheric chemistry. While attention has been paid mostly to anthropogenic sources of MEK, recently it has been shown that biogenic sources are globally as important as anthropogenic ones. However, the origin of biogenic MEK has yet to be completely elucidated. We present the full mechanism by which within-plant transformation of methyl vinyl ketone (MVK) and, to a minor extent, of 2-butanol and 3-buten-2-ol, is a source of biogenic MEK. Such transformation is observed in red oak for both exogenous MVK, taken up from the atmosphere, and endogenous MVK generated within a plant when it experiences stress (e.g. heat stress). Endogenous MVK emitted by plants is typically explained by within-plant oxidation of isoprene caused by oxidative stress. In this study we show that MVK and MEK emissions caused by heat stress are not related to isoprene in isopreneemitting plants, implying that the massive carbon investment that plants commit to isoprene production is not explained by a direct antioxidant role. The presented mechanism can be important for inclusion in plant emission and in plantatmosphere interaction models.
\end{abstract}

\section{Introduction}

Isoprene is the major biogenic volatile organic compound (VOC) emitted by the biosphere into the atmosphere. A wide breadth of research, and particularly the latest studies employing genetic engineering to produce transgenic plants with modified isoprene emission, have demonstrated that isoprene increases plant tolerance to oxidative stresses, caused by factors such as high temperature and ozone (Behnke et al., 2007; Loivamäki et al., 2007; Sasaki et al., 2007; Sharkey et al., 2005; Vickers et al., 2009, 2011). However, the mechanisms by which isoprene confers resistance against oxidative stresses remain unclear. A first hypothesis is that isoprene strengthens thylakoid membranes (Velikova et al., 2011). It has been shown that under physiological conditions there are less than a hundred isoprene molecules per million lipid molecules in the membranes (Harvey et al., 2015), casting doubt on this mechanism. However, there is evidence that isoprene positively influences the photosynthetic electron flow, reducing heat dissipation mechanisms and stabilizing thylakoid membranes, especially under stressful environments (Pollastri et al., 2014; Velikova et al., 2011). Recently, it has been shown that isoprene may act as a signaling molecule, inducing up-regulation of phenylpropanoid biosynthetic genes, indirectly enhancing plant resistance to heat and light stress (Harvey and Sharkey, 2016). Alternatively, isoprene may simply act as a proxy of induced activation of secondary metabolism (Tattini et al., 2015). A last hypothesis is that isoprene scavenges reactive oxygen species (ROS) by direct or indirect reaction (Loreto and Velikova, 2001). ROS exert an important signaling role in plants (Mittler et al., 2011) but can be generated in high amounts upon abiotic stresses, leading to cell damage and programmed cell death (Delledonne et al., 2001). Isoprene biosynthesis has been ascribed a ROS quenching effect, but, again, iso- 
prene concentration in the leaf may be too low; abundant lipids and carotenoids can react with ROS much more rapidly than isoprene (Harvey et al., 2015). Nevertheless, emission of putative isoprene oxidation products that may be formed upon isoprene reaction with ROS has been reported, e.g. in a tropical rainforest mesocosm (Jardine et al., 2012), mango trees (Jardine et al., 2012, 2013), and creosote bush (Jardine et al., 2010). The putative isoprene oxidation products, the carbonyls methyl vinyl ketone (MVK) and methacrolein (MACR), are cytotoxic and must be rapidly removed from leaves once formed (Oikawa and Lerdau, 2013; Vollenweider et al., 2000). Plants also rapidly take up MACR and MVK (Andreae et al., 2002; Karl et al., 2004, 2005, 2010), suggesting that these compounds may be metabolized. Detoxification mechanisms for MACR have been reported (Muramoto et al., 2015), whereas this is not the case for MVK.

Methyl ethyl ketone (MEK) is an important oxygenated volatile organic compound (OVOC) for the atmosphere. In several studies the MEK concentration in the free troposphere has been reported to be approximately $25 \%$ of the concentration of acetone (Moore et al., 2012; Singh et al., 2004). However, MEK has a much shorter lifetime than acetone due to a much higher reactivity (by about 1 order of magnitude) with hydroxyl radical $\left(\mathrm{OH}, k_{\mathrm{OH}}=1.15 \times\right.$ $10^{-12} \mathrm{~cm}^{3} \mathrm{~s}^{-1}$ at $296 \mathrm{~K}$; Chew and Atkinson, 1996), which makes it important to total $\mathrm{OH}$ reactivity (Nölscher et al., 2016). Both biogenic and anthropogenic sources contribute to global atmospheric MEK (Yáñez-Serrano et al., 2016). In urban environments, MEK is typically the most abundant ketone after acetone (Feng et al., 2005; Grosjean et al., 1996), as it is widely produced in industrial processes (Legreid et al., 2007; Sin et al., 2001). The regional background of MEK was once attributed to anthropogenic sources only. More recent findings suggest that the biogenic source of MEK is comparable to the anthropogenic source (Yáñez-Serrano et al., 2015, 2016), but the origin of biogenic MEK has not been fully elucidated so far. Direct emission of MEK from vegetation seems to be the largest contribution since only a few minor biogenic VOCs (e.g, n-butane and 2-butanol) can lead to MEK via atmospheric oxidation (de Gouw et al., 2003; Jenkin et al., 1997; Singh et al., 2004; Sommariva et al., 2011). We recently found a possible relation between the detoxification by vegetation of MVK and the biogenic emission of MEK (Cappellin et al., 2017). We suggested that MVK could be efficiently detoxified by reduction reactions which lead mostly to MEK and to a minor extent to 2-butanol, though the full interconversion scheme was not studied.

In this study we explore the links between the production of isoprene from photosynthetic carbon, within-plant isoprene oxidation, and the biogenic emission of putative isoprene oxidation products MVK, MEK, and 2-butanol. We performed a series of fumigation experiments in which leaves were exposed to exogenous levels of a single carbonyl, and investigated the relationships between the up- take of each compound and the release of related products. We then studied the emission of carbonyls by leaves under progressively higher temperature conditions that likely inhibit photosynthesis and increase isoprene biosynthesis and the oxidative environment within leaves. We finally explored whether MVK, MEK, and 2-butanol produced under heat stress are products of in-plant isoprene oxidation by determining whether they share a labelling pattern with isoprene when leaves are fed ${ }^{13} \mathrm{CO}_{2}$. Different labelling patterns would indicate that emitted carbonyls are not isoprene oxidation products, and would cast doubt on the hypothesis that isoprene acts as an antioxidant by reacting with ROS inside leaves.

\section{Results}

\subsection{Fumigation of leaves with OVOCs}

Individual plants were fumigated with MVK, MEK, 2butanol, 3-buten-e-ol, or MACR, as described in the Materials and methods and Fig. 1. Both MVK and MACR were efficiently taken up by the fumigated leaves but, while MVK was continuously transformed into other volatile products that were subsequently released (Fig. 1a), in the case of MACR only a transient release of other volatiles was observed (Fig. 1e). MVK reduction generated either MEK or 3-buten-2-ol, depending on whether the alkene moiety or the carbonyl moiety of MVK is reduced. Further reduction reactions converted MEK and 3-buten-2-ol into 2-butanol (see also Fig. 1b and d). Conversion of 3-buten-2-ol to MEK is also possible (Fig. 1d). The release of MEK, 3-buten2-ol, and 2-butanol corresponded to $97 \pm 6 \%$ (mean \pm SD, $n=3$ ) of the total MVK uptake (Table S1 in the Supplement). Compound identification is corroborated by corollary GC-MS experiments (Fig. S1). In the MEK fumigation experiments (Fig. 1b), the release of 2-butanol corresponded to $87 \pm 22 \%$ of the total uptake of MEK. Remarkably, 2-butanol and 3-buten-2-ol may also convert into MEK (Fig. 1c, d). In the 2-butanol fumigation experiments (Fig. 1c), the release of MEK corresponded to $90 \pm 50 \%$ of the total uptake of 2-butanol. In the 3-buten-2-ol fumigation experiments (Fig. 1d), the release of MEK and 2-butanol corresponded to $56 \pm 18 \%$ and $22 \pm 6 \%$ of the total uptake of 3-buten2-ol, respectively. Finally, in the MACR fumigation experiment (Fig. 1e) we observed a small transient release of isobutyraldehyde, in an amount accounting for $6.5 \pm 1.3 \%$ of the MACR taken up, and, to a lesser extent, of 2-methallyl alcohol $(0.7 \pm 0.5 \%)$ and isobutanol $(2.1 \pm 0.5 \%)$. The total emission of these three compounds corresponded to $9.3 \pm 1.4 \%$ of the total MACR taken up.

\subsection{Emission of isoprene and OVOCs under heat stress}

Emissions from darkened, unstressed leaves were measured (Fig. 2a). As expected (Loreto and Sharkey, 

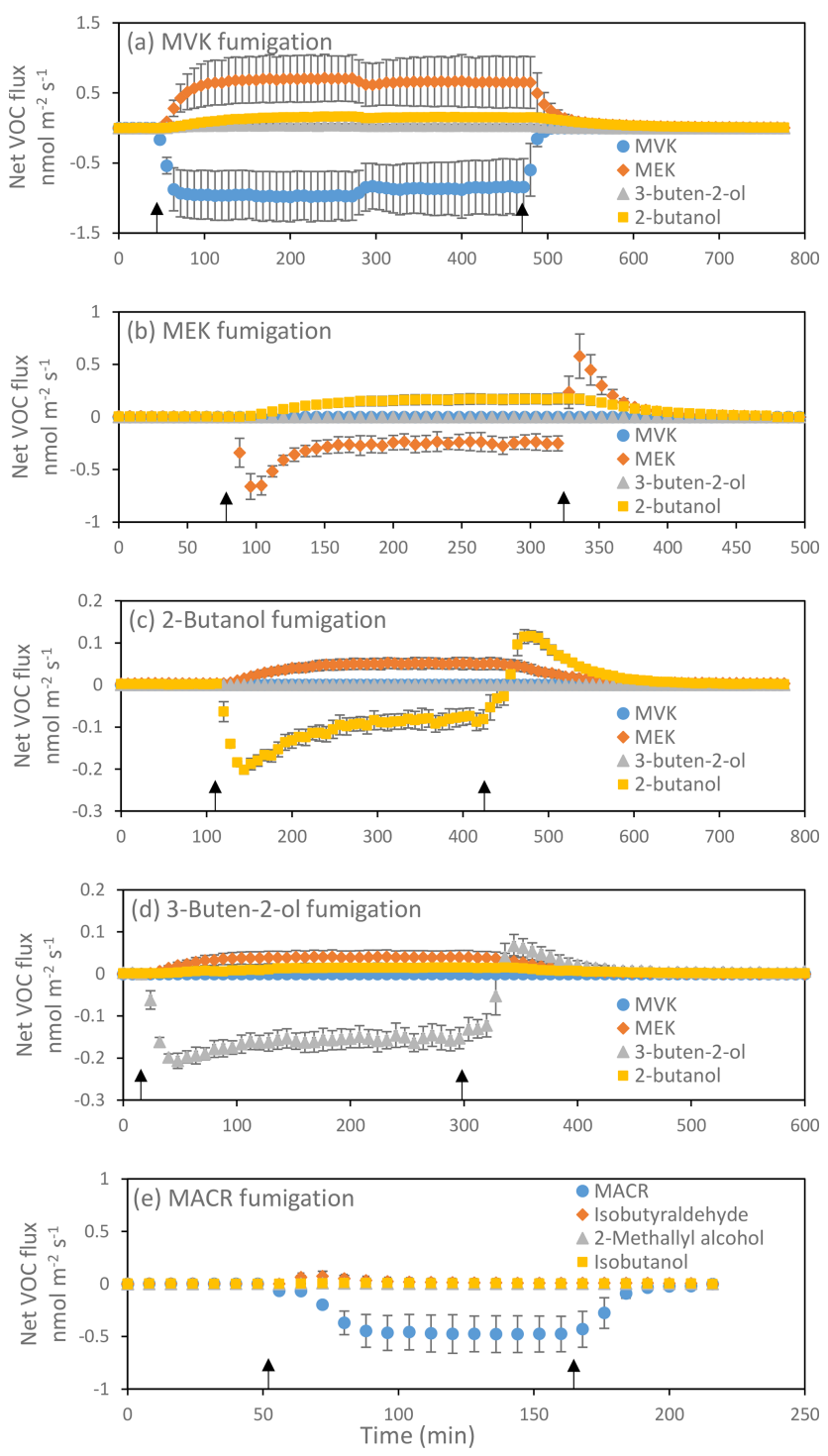

Figure 1. Uptake of MVK (a), MEK (b), 2-butanol (c), 3-butene-ol (d) and MACR (e) and emission of their oxidized or reduced products in red oak leaves. Results are reported as mean \pm standard deviation $(n=3)$. Negative values denote the uptake and positive values the emission of volatiles. Black arrows indicate the beginning and the end of the fumigation. In (b), the pulses of MEK uptake at the beginning of the fumigation and of MEK release after the end of the fumigation correspond to formation and release, respectively, of a MEK pool dissolved into the leaf water. At equilibrium the uptake of MEK and subsequent release of 2-butanol is constant and indicates a constant rate of MEK transformation within leaves. Analogous considerations can be made for 2-butanol and 3-buten2-ol in (c) and (d), respectively.

1990), a very small basal emission of isoprene $(0.015 \pm$ $0.004 \mathrm{nmol} \mathrm{m}^{-2} \mathrm{~s}^{-1}$, mean $\pm \mathrm{se}, n=6$ ) was found. In these leaves the emissions of putative isoprene oxidation products (MVK + MACR + ISOPOOH, Fig. 2b) and their reduction products (MEK and 2-butanol; Figure 2c and d, respectively) were near background level, and dark respiration was low $\left(0.49 \pm 0.07 \mu \mathrm{mol} \mathrm{m}{ }^{-2} \mathrm{~s}^{-1}\right.$, Fig. 2e). When darkened red oak leaves were exposed to mild heat stress $\left(35^{\circ} \mathrm{C}\right.$ for $\left.2 \mathrm{~h}\right)$ a small but statistically significant increase in isoprene emission to $0.034 \pm 0.007 \mathrm{nmol} \mathrm{m}^{-2} \mathrm{~s}^{-1}$ was observed. Emission of MVK + MACR + ISOPOOH was detected at a level of $0.002 \pm 0.001 \mathrm{nmol} \mathrm{m}^{-2} \mathrm{~s}^{-1}$, and emissions of further transformation products of MVK were also detected, namely MEK $\left(0.005 \pm 0.001 \mathrm{nmol} \mathrm{m}^{-2} \mathrm{~s}^{-1}\right)$ and 2-butanol $\left(0.007 \pm 0.001 \mathrm{nmol} \mathrm{m}^{-2} \mathrm{~s}^{-1}\right)$. However, only the increase in 2-butanol was statistically significant compared to unstressed leaves. Dark respiration also increased to $0.8 \pm 0.2 \mu \mathrm{mol} \mathrm{m} \mathrm{m}^{-2} \mathrm{~s}^{-1}$. More severe heat stress was then imposed, maintaining the darkened leaves at $45^{\circ} \mathrm{C}$ for $2 \mathrm{~h}$. This led to a further significant increase in isoprene emission $\left(0.08 \pm 0.01 \mathrm{nmol} \mathrm{m}^{-2} \mathrm{~s}^{-1}\right)$ (Fig. 2a). Emission of MVK + MACR + ISOPOOH also increased to $0.006 \pm$ $0.001 \mathrm{nmol} \mathrm{m}^{-2} \mathrm{~s}^{-1}$ (Fig. 2b), and emission of MEK and 2butanol increased to $0.029 \pm 0.007 \mathrm{nmol} \mathrm{m}^{-2} \mathrm{~s}^{-1}$ and $0.033 \pm$ $0.007 \mathrm{nmol} \mathrm{m}^{-2} \mathrm{~s}^{-1}$, respectively (Fig. 2c, d). Dark respiration also increased to $1.1 \pm 0.1 \mu \mathrm{mol} \mathrm{m}^{-2} \mathrm{~s}^{-1}$ (Fig. 2e). All these changes were statistically significant with respect to the values measured at $25^{\circ} \mathrm{C}$. After a recovery phase of $2 \mathrm{~h}$ at room temperature $\left(25^{\circ} \mathrm{C}\right)$, pre-stress emissions were again found for all compounds (Fig. 2a-e).

The same experiment was repeated on illuminated red oak leaves (Fig. 2f-j). Non-stressed leaves (maintained at $25^{\circ} \mathrm{C}$ ) photosynthesized at a rate of $1.2 \pm$ $0.2 \mu \mathrm{mol} \mathrm{CO}_{2} \mathrm{~m}^{-2} \mathrm{~s}^{-1}$ (Fig. 2j) and emitted isoprene at a rate of $3.7 \pm 0.5 \mathrm{nmol} \mathrm{m}^{-2} \mathrm{~s}^{-1}$ (Fig. 3f). These values for carbon assimilation and isoprene emission are consistent literature findings, considering the light intensity to which plants were exposed (e.g. see Loreto and Sharkey, 1990). In non-stressed leaves, the emission of MVK + MACR + ISOPOOH was below the detection limit (Fig. 2g) and the emissions of MEK and 2-butanol were also close to background (Fig. 2h, i). Exposure to $35^{\circ} \mathrm{C}$ for $2 \mathrm{~h}$ led to a non-significant decrease in photosynthesis (Fig. 2j) and to a large increase in isoprene emission, reaching $10.8 \pm 1.3 \mathrm{nmol} \mathrm{m}^{-2} \mathrm{~s}^{-1}$ (Fig. 2f). Detectable emission rates of MVK + MACR + ISOPOOH were present (Fig. 2g), and MEK and 2-butanol emissions were also detectable (Fig. 2h, i). However, the change in emissions compared to that observed at $25^{\circ} \mathrm{C}$ was statistically significant only for 2-butanol. Severe stress $\left(45^{\circ} \mathrm{C}\right.$ for $2 \mathrm{~h}$ ) caused a reduction in the emission of isoprene as compared to the maximum emission observed at $35^{\circ} \mathrm{C}$ (Fig. 2f), and photosynthesis was also inhibited (Fig. 2j). However, the emission of MVK + MACR + ISOPOOH increased to $0.006 \pm 0.002 \mathrm{nmol} \mathrm{m}^{-2} \mathrm{~s}^{-1}$ (Fig. $2 \mathrm{~g}$ ), and MEK and 2-butanol increased to $0.026 \pm 0.004 \mathrm{nmol} \mathrm{m}^{-2} \mathrm{~s}^{-1}$ and $0.025 \pm 0.005 \mathrm{nmol} \mathrm{m}^{-2} \mathrm{~s}^{-1}$, respectively (Fig. $2 \mathrm{~h}$, i). After recovering for $2 \mathrm{~h}$ at room temperature $\left(25^{\circ} \mathrm{C}\right)$, VOC emissions and photosynthetic rate were similar to those of prestressed leaves (Fig. 2f-j). 

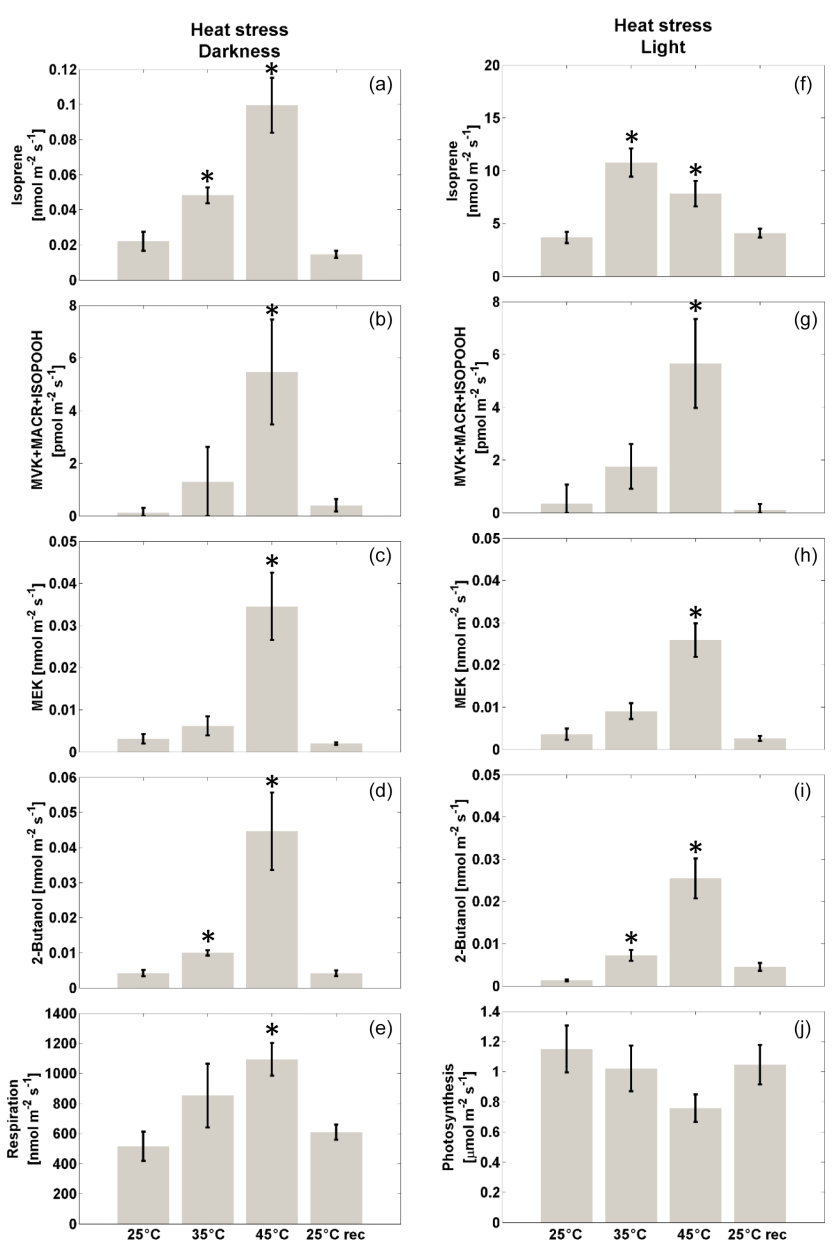

Figure 2. Left: net flux of isoprene (a), $\mathrm{MVK}+\mathrm{MACR}+\mathrm{ISOPOOH}$ (b), products from MVK reduction (MEK, c, and 2-butanol, d) and respiration (e) upon exposure to moderate $\left(35^{\circ} \mathrm{C}\right)$ or severe $\left(45^{\circ} \mathrm{C}\right)$ heat stress, and recovery to $25^{\circ} \mathrm{C}$ by red oak plants in the dark. The compound grouping is based on PTR-ToF-MS in $\mathrm{H}_{3} \mathrm{O}^{+}$mode. Results are reported as mean \pm standard error $(n=6)$. Asterisks indicate significant differences (Kruskal-Wallis, $p<0.05$ ) compared to the unstressed $\left(25^{\circ} \mathrm{C}\right)$ case. Right: emission of isoprene (f), $\mathrm{MVK}+\mathrm{MACR}+\mathrm{ISOPOOH}(\mathrm{g})$, products from MVK reduction (MEK, $\mathbf{h}$, and 2-butanol, i), and photosynthesis (j) upon exposure to moderate $\left(35^{\circ} \mathrm{C}\right)$ or severe $\left(45^{\circ} \mathrm{C}\right)$ heat stress, and recovery to $25^{\circ} \mathrm{C}$ in red oak plants in the light (ca. $90 \mu \mathrm{mol} \mathrm{m}{ }^{-2} \mathrm{~s}^{-1}$ light intensity). The compound grouping is based on PTR-ToF-MS in $\mathrm{H}_{3} \mathrm{O}^{+}$mode. Results are reported as mean \pm standard error $(n=6)$. Asterisks indicate significant differences (Kruskal-Wallis, $p<0.05)$ compared to the unstressed $\left(25^{\circ} \mathrm{C}\right)$ control.

\section{$2.3 \quad{ }^{13} \mathrm{C}$ labelling of isoprene and OVOCs}

To provide better insights into isoprene production and possible within-leaf oxidation under severe heat stress, plants were exposed to isotopically labelled $\mathrm{CO}_{2}$ at $45^{\circ} \mathrm{C} .{ }^{13} \mathrm{C}$ labelling of isoprene was clearly visible. All ${ }^{13} \mathrm{C}$-labelled isoprene isotopomers $(\mathrm{m} / z=70-74)$ appeared, and the unla-

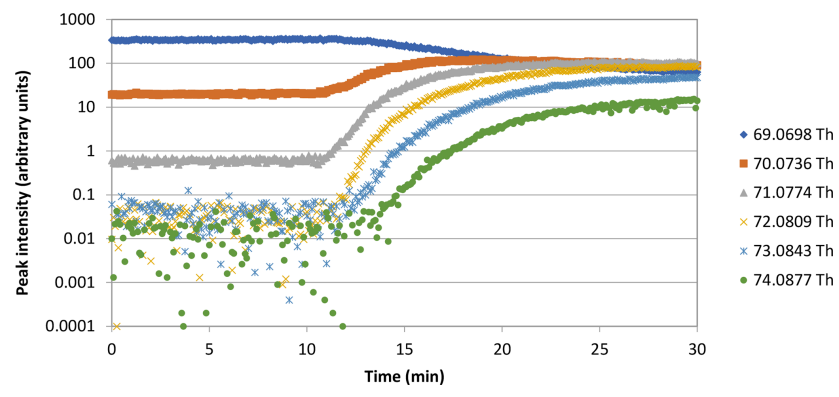

Figure 3. Labelling of isoprene emitted by red oak leaves upon ${ }^{13} \mathrm{CO}_{2}$-feeding in the air. Fully labelled ${ }^{13} \mathrm{CO}_{2}$ is constantly supplied to the plants starting from time $T=10 \mathrm{~min}$.

belled isoprene $(m / z=69)$ declined rapidly (Fig. 3). After $20 \mathrm{~min}$ of ${ }^{13} \mathrm{CO}_{2}$ labelling, the percentage of labelled isoprene was above $80 \%$, and a stable labelled fraction of $95 \pm 1 \%$ of the emitted isoprene was reached ca. $40 \mathrm{~min}$ after starting the ${ }^{13} \mathrm{CO}_{2}$ fumigation (Fig. 4a). However, MVK + MACR + ISOPOOH, MEK, and 2-butanol were not labelled by ${ }^{13} \mathrm{C}$. Even after $2 \mathrm{~h}$ of ${ }^{13} \mathrm{CO}_{2}$ labelling, the isotopic ratios of MVK + MACR + ISOPOOH (Fig. 4b) and those of MEK and 2-butanol (Fig. 4c, d) remained at their natural abundance levels.

\section{Discussion}

There are consistent indications that MEK is released by vegetation at the leaf-, canopy-, and ecosystem-scale and that biogenic sources influence global atmospheric concentrations of MEK (Yáñez-Serrano et al., 2016, and references therein). However, no mechanism for biogenic MEK production has been demonstrated previously. It has been hypothesized that MEK could be generated following similar pathways to acetone, as a by-product of cyanogenesis in the transformation of a cyanohydrin lyase (Yáñez-Serrano et al., 2016). This idea has not been proven and emission would be limited to cyanogenic plants. Plant uptake of atmospheric MVK is a well-established phenomenon (Karl et al., 2010) and bidirectional exchange of MVK has been sometimes reported (Karl et al., 2005). Emissions of MVK and MEK have been rarely measured at leaf level and are challenging to measure because (i) emissions are small, especially in the case of MVK; (ii) separation of leaf and atmospheric sources in the presence of high isoprene emissions is difficult. Jardine et al. $(2012,2013)$ reported emissions of MACR and MVK in isoprene-emitting trees. They attributed carbonyl emissions to within-leaf isoprene oxidation, possibly by ROS induced under environmental stress conditions (e.g. heat stress).

Our results confirm the emission of carbonyls and show that the reduction of several carbonyls may occur in plants. In particular, we show that reduction reactions transform MVK into MEK, 3-buten-2-ol, and 2-butanol, and that the conver- 


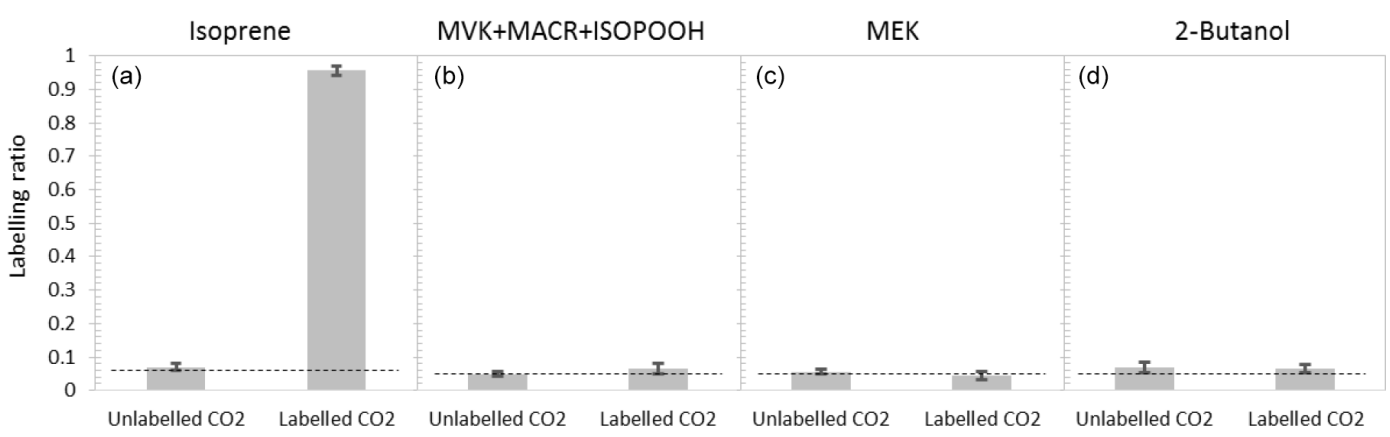

Figure 4. Emission of isoprene (a), MVK + MACR + ISOPOOH (b), MEK (c), and 2-butanol (d) in red oak plants heat stressed at $45^{\circ} \mathrm{C}$ for $2 \mathrm{~h}$ in the light, under ${ }^{12} \mathrm{CO}_{2}$ or ${ }^{13} \mathrm{CO}_{2}$ atmosphere. Dashed horizontal lines represent natural abundances of isotopic compounds.

sion of MEK into 2-butanol occurs in both directions (Fig. 5). This mechanism is the first possible pathway for the biogenic production and emission of MEK. The results also suggest that within-plant isoprene oxidation is not the source of these VOCs in our experiments.

Our fumigation experiments establish a causal link between-plant metabolisms of MVK and MEK production. Reaction yield calculations were performed considering the net total amount of MVK taken up during the experiment and the net total amount of MEK released. We show that $73 \pm 10 \%$ of the MVK taken up by leaves was converted into MEK. Most of the remaining MVK was converted into 3-buten-2-ol and 2-butanol. Thus $97 \pm 6 \%$ of MVK uptake was re-emitted as other volatile products. These data confirm previous reports at Harvard Forest, corroborated by laboratory experiments, where a correlation between uptake of MVK and emission of MEK, 2-butanol, and 3-buten-2-ol was found (Cappellin et al., 2017). The implication is that the metabolism of MVK is a likely source of MEK emissions.

Whether other mechanisms for MEK production by plants exist remains an open question. Processes on the leaf surface such as MVK adsorption or metabolization by leaf surface bacteria have been shown to be of minor importance in previous investigations of ketone and aldehyde leaf uptake (Omasa et al., 2000; Tani et al., 2010, 2013; Tani and Hewitt, 2009 , p. 20). Future studies should investigate the fraction of global biogenic MEK emissions that could be accounted for by the proposed production mechanism.

Rapid transformation of MVK by secondary reactions can be interpreted as a necessary and efficient detoxification mechanism. MVK toxic effects include the accumulation of hydrogen peroxide and the activation of some stressresponsive genes (Alméras et al., 2003; Vollenweider et al., 2000). MVK metabolism has been reported in several plants (Karl et al., 2010; Tani et al., 2010). It has also been demonstrated that various plant cells are able to reduce unsaturated ketones (Kergomard et al., 1988). Long-term fumigation experiments with houseplants (Tani and Hewitt, 2009) have established that the uptake of several aldehydes and ketones exceeded by orders of magnitude the amount dissolved in leaf water, thus implying their metabolization as well. Transformation of MVK into MEK may be especially important in stressed plants as oxidative stress increases and endogenous production of MVK occurs (Jardine et al., 2012). The fumigation experiments suggest that the process can occur for exogenous MVK as well. Hence, the reduction mechanism also provides an explanation for plant uptake of MVK, a cytotoxic compound, which has been observed in many studies (e.g. Brilli et al., 2016; Karl et al., 2005, 2010).

MACR was also efficiently metabolized, consistent with other literature reports on tomato plants (Muramoto et al., 2015). In this case, however, detected volatiles produced by MACR reduction represented only about $9 \%$ of the MACR uptake. By analogy with the case of MVK, the expected reduction products of MACR would be isobutyraldehyde, 2methylprop-2-en-1-ol, and isobutyl alcohol. However, only a transient release of such products was detected. Isobutyraldehyde emission accounted for $6.5 \%$ of the MACR uptake within $2 \mathrm{~h}$, confirming results from a previous study on tomato plants (6.4\%; Muramoto et al., 2015). Muramoto et al. (2015) reported that most MACR in the leaf undergoes glutathionylation. Therefore, no MACR volatile products are released. Our results are in line with this interpretation, as MACR uptake implies a sink within leaves, suggesting a continuous metabolization of the compound, but the metabolic products are not released as volatiles.

The foliar uptake of MVK and MACR was rapid and sustained throughout the entire fumigation period, suggesting a large and fast metabolic sink. On the other hand, the uptake of secondary transformation products (namely MEK, 3buten-2-ol, and 2-butanol) was not sustained, indicating that the metabolic sink was smaller and insufficient to rapidly scavenge the metabolites, leading to their temporary accumulation within leaves. Upon ending the fumigation, accumulated MEK, 3-buten-2-ol, and 2-butanol were released from the leaves back to the atmosphere (Fig. 2b, c, d).

A further aim of this study was to verify whether carbonyls emitted by plants come from isoprene oxidation in plants, as elsewhere proposed (Jardine et al., 2012). The experiments were conducted on red oak, one of the strongest 


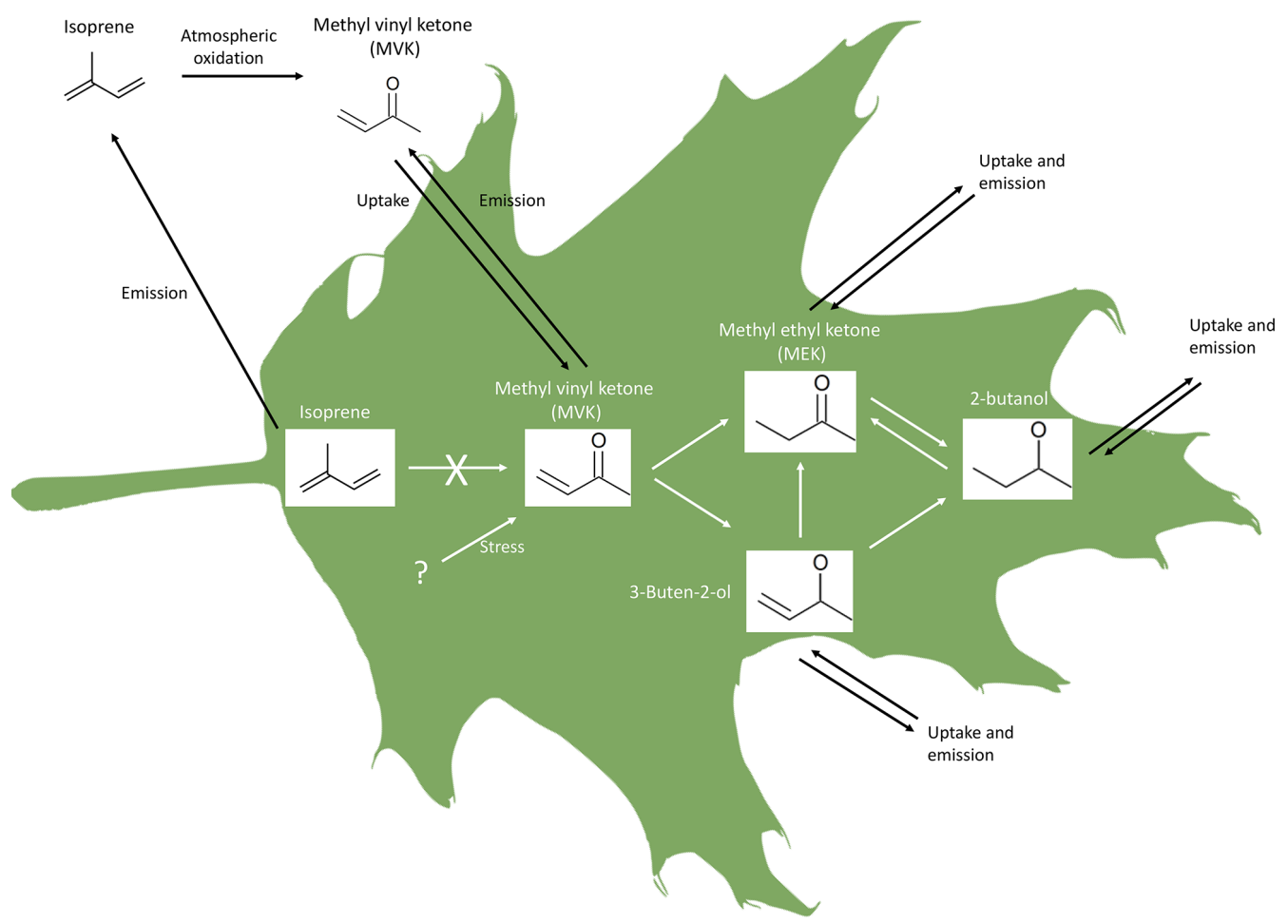

Figure 5. Schematics of MVK, MEK, 3-buten-2-ol, and 2 butanol origin and interconversion in leaves, as suggested by this study. The uptake of MEK, 3-buten-2-ol, and 2-butanol has not been reported so far but it is in principle possible given the present results.

isoprene-emitting plant species (Loreto and Sharkey, 1990). As isoprene biosynthesis is light- and temperature-dependent (Loreto and Sharkey, 1990), an increase in isoprene transformation products would be expected when leaves are illuminated and exposed to moderately high temperatures. This behaviour was indeed represented in the present data (Fig. 2). Under heat stress, photosynthesis and isoprene emission generally decouple and carbon sources other than direct products of photosynthetic carbon fixation are used for isoprene biosynthesis (Brilli et al., 2007). When leaves were severely heat-stressed we did not observe the expected uncoupling between photosynthesis and isoprene emission, as both parameters decreased. However, MVK + MACR + ISOPOOH, MEK, and 2-butanol increased. This increase would be predicted to occur under an increasingly oxidative environment where molecular $\mathrm{O}_{2}$ is directly photoreduced instead of being used for photosynthetic electron transport. Interestingly, the amount of MVK + MACR + ISOPOOH, MEK, and 2butanol was similarly enhanced in illuminated and darkened leaves under the effect of high temperatures, despite the fact that no photosynthesis and minimal isoprene emission was present in darkness.

This unexpected observation was followed up with measurements of ${ }^{13} \mathrm{C}$ labelling to further characterize the carbon source of MVK, MEK, and 2-butanol. As photosynthetic metabolites and isoprene label very quickly and almost totally when exposed to a ${ }^{13} \mathrm{CO}_{2}$ atmosphere (Delwiche and
Sharkey, 1993; see also Figs. 3, 4), we would expect that putative isoprene oxidation products and their further transformation products would be quickly and totally labelled as well. On the other hand, if carbon sources other than direct photosynthetic metabolites (including isoprene) are used for their biosynthesis, these compounds would not be labelled. The observation that no ${ }^{13} \mathrm{C}$ labelling appeared in any of the emitted carbonyls suggests that isoprene is not involved in their biosynthesis. We are not aware of isoprene pools that label slowly in plants (Niinemets et al., 2004). However, sources independent of freshly assimilated carbon contribute to isoprene production when photosynthesis is stress-constrained (Brilli et al., 2007). Photorespiratory carbon may contribute to isoprene production, especially during dynamic changes of environmental conditions (Jardine et al., 2014). However, photorespiration also labels quite rapidly with ${ }^{13} \mathrm{CO}_{2}$ (Delfine et al., 1999), and ${ }^{13} \mathrm{C}$ would appear in MVK and MEK skeletons if contributed by photorespiratory carbon.

Isoprene labelling experiments using ${ }^{13} \mathrm{C}$-enriched glucose under $\mathrm{CO}_{2}$-free air conditions have provided a clear indication that isoprene may also incorporate carbon via the glycolytic pathway (Affek and Yakir, 2003), and possibly also by re-fixation of respiratory $\mathrm{CO}_{2}$ (Loreto, 2004; Loreto et al., 2007). This alternative carbon source can become prevalent when photosynthesis is stress-inhibited (Brilli et al., 2007), and may sustain small yet measurable emissions 
of isoprene in $\mathrm{CO}_{2}$-free air (Affek and Yakir, 2002) or in detached leaves with no photosynthetic activity (Brilli et al., 2011; Harrison et al., 2013; Loreto and Schnitzler, 2010). However, under the conditions used here photosynthesis was never dramatically impaired and isoprene emission was labelled completely, even under heat stress. We conclude that the emitted carbonyls are not isoprene oxidation products but derive from a different metabolism. It should be noted, however, that in nature, under high UV radiation, the emission of isoprene is generally far larger than that found in our experiment, and the oxidation potential of the atmosphere is also greater. Thus, we cannot completely rule out that isoprene also oxidizes forming carbonyls, namely MVK and MACR, in nature. If not isoprene, then what is the source of the emitted carbonyls in plants? MVK and MACR are peroxidation products of the trienoic fatty acid contained in chloroplast membranes (Alméras et al., 2003; Kai et al., 2012), and cause cytotoxicity once formed in leaves. MVK is also a component of flower scent (Knudsen et al., 1993) and may be a lipid peroxidation product, activating the expression of stress-related genes in Arabidopsis (Vollenweider et al., 2000). As we have demonstrated that isoprene is not responsible for the production of MVK and its transformation products in plants, further research should concentrate on investigating the relationships between emitted carbonyls and lipid catabolism in cellular membranes.

\section{Materials and methods}

\subsection{Plant material and experimental design}

Experiments were performed on 2-year-old red oaks (Quercus rubra) obtained from a local nursery (Malleier, Lana, Italy). A total of 40 plants were placed in $5 \mathrm{~L}$ polypropylene pots (Plastecnic, Perego, Italy), using TerraBrill ${ }^{\circledR}$ peat moss (Agrochimica, Bolzano, Italy). Prior to the experiments, plants were grown for 60 days in a greenhouse under a $14 \mathrm{~h}$ photoperiod with a light: dark temperature regime of $24.0: 19.0^{\circ} \mathrm{C}, 60 \pm 10 \%$ relative humidity, and ca. $90 \mu \mathrm{mol} \mathrm{m} \mathrm{m}^{-2} \mathrm{~s}^{-1}$ light intensity. Plants were watered every 3 days and developed fully expanded leaves after 5 weeks. A total of 4 days prior to the experiments, plants were transferred from the growth chamber into a climate cabinet (Climacell 707, BMT Medical Technology, Brno, Czech Republic). The climatic cabinet was employed to maintain constant climatic conditions (fumigation experiments) or to apply heat stress while maintaining all other parameters constant (heat stress experiments). The early transfer allowed plant recovery from accidental mechanical injures and adaptation to the new environment. The climate cabinet was set with the same parameters as the greenhouse, but at a constant temperature of $25^{\circ} \mathrm{C}$ (except for heat stress experiments), and interfaced with the proton transfer reaction time-of-flight mass spectrometry (PTR-ToF-MS) via polyetheretherketone
(PEEK) capillary tubes (ca. $1.5 \mathrm{~m}$ length $\times 1.01 \mathrm{~mm} \mathrm{ID}$; temperature: $110^{\circ} \mathrm{C}$ (part outside the climatic chamber, ca. $1 \mathrm{~m}$ ), flow: $40 \mathrm{sccm})$.

One day prior to the start of the experiments, a shoot portion of each plant was enclosed within a Teflon (perfluoroalkoxy; PFA) bag and three capillary tubes were attached to each shoot to be monitored. The three tubes included the following: a PFA tube providing a constant flow of humidified zero air (eventually including fumigation VOCs during fumigation experiments) to the VOC bag, a second PFA tube removing the overflow air, and a PEEK capillary tube sampling the VOC-bag air into the PTR-ToF-MS. As negative control, volatiles were monitored in parallel on an empty VOC bag connected to the PTR-ToF-MS with the same tubing system described above.

Fumigation experiments were performed on three independent plants and on the empty VOC bag as a negative control. New plants were used for every fumigation. Pure liquid standards of each chemical were purchased from SigmaAldridge and diluted with Milli-Q water. A Liquid Calibration Unit (Ionicon Analytik GmbH, Innsbruck, Austria) was employed to continuously nebulize $10 \mu \mathrm{L} \mathrm{min}^{-1}$ of the diluted standard into $1 \mathrm{~L} \mathrm{~min}^{-1}$ of synthetic air generated from a cylinder (Aria Medicinale F.U., Rivoira) made by $80 \% \mathrm{~N}_{2}$, $20 \% \mathrm{O}_{2}$, and $400 \mathrm{ppm} \mathrm{CO}_{2}$. The volume mixing ratio of the compound used for the fumigation in the VOC-bag inlets was the following: $290 \mathrm{ppbv}$ for MVK, $330 \mathrm{ppbv}$ for MEK, $90 \mathrm{ppbv}$ for 2-butanol, $96 \mathrm{ppbv}$ for 3-buten-2-ol, $140 \mathrm{ppbv}$ for MACR. Fluxes were controlled using mass flow controllers (MKS Instruments, Deutschland $\mathrm{GmbH}$ ). Water vapour was added to the air stream by constantly nebulizing water via a Liquid Calibration Unit (Ionicon Analytik GmbH, Innsbruck, Austria) to reach a RH of $60 \%$.

Fumigation experiments were performed separately for each chemical using fresh plants from the greenhouse. Gas flow measurements in the PFA tubes providing the fumigation gas mixture were conducted using a flow meter at the beginning and at the end of each experiment (Defender 530, DryCal Technology, MesaLabs) and was ca. $250 \mathrm{sccm}$ for each VOC bag. Leaf area enclosed in the bag was measured using open-source software (ImageJ, available at http: //imagej.net/Welcome, last access: 31 July 2018). VOC uptake or release by the plants was calculated as the difference between VOC concentrations in the plant VOC bag and in the empty VOC bag. Results were normalized by the total leaf area enclosed in the bag, and by the incoming air flows.

Heat stress experiments were conducted using a similar set-up to the fumigation experiments. After acclimation for 4 days, during the day of the experiment, basal emissions at $25^{\circ} \mathrm{C}$ were measured for $2 \mathrm{~h}$ before raising the temperature to $35^{\circ} \mathrm{C}$ (mild stress) and subsequently to $45^{\circ} \mathrm{C}$ (severe stress). Each temperature was maintained for $2 \mathrm{~h}$. Measurements were continued during the recovery phase at $25^{\circ} \mathrm{C}$ for a further $2 \mathrm{~h}$. Transitions between different temperatures required a $15 \mathrm{~min}$ ramp. 
Experiments using labelled ${ }^{13} \mathrm{CO}_{2}$ were performed as follows. A $1 \mathrm{~L}$ cylinder of ${ }^{13} \mathrm{C}$-labelled $\mathrm{CO}_{2}$ was purchased from Sigma-Aldrich ( 99 atom $\%{ }^{13} \mathrm{C}$ purity). The heat stress experiment at $45^{\circ} \mathrm{C}$ described above was repeated by switching the $\mathrm{CO}_{2}$ in the air stream from unlabelled $\mathrm{CO}_{2}$ to ${ }^{13} \mathrm{C}$ labelled $\mathrm{CO}_{2}$. The labelling was triggered when the signals for isoprene and isoprene primary and secondary oxidation products became stable after the temperature change, i.e. about $1 \mathrm{~h}$ after the onset of the stress. The temperature was kept constant at $45^{\circ} \mathrm{C}$ while feeding ${ }^{13} \mathrm{C}$-labelled $\mathrm{CO}_{2}$. Results were compared to analogous experiments employing unlabelled $\mathrm{CO}_{2}$.

\subsection{Gas analysis}

Trace gas analysis performed via a PTR/SRI-ToF-MS 8000 (Ionicon Analytik GmbH, Innsbruck, Austria). PEEK capillary tubes directly sampled the air mixture from each VOC bag to the instrument inlet. A valve system allowed switching between the enclosures every $2 \mathrm{~min}$. The PTR/SRI-ToF-MS was equipped with a switchable reagent ion system (Jordan et al., 2009), allowing either $\mathrm{H}_{3} \mathrm{O}^{+}$or $\mathrm{NO}^{+}$to be selected as the primary ion. Measurements were generally taken using $\mathrm{H}_{3} \mathrm{O}^{+}$ion chemistry, while for the fumigation experiments measurements were taken in both modes in order to strengthen compound identification. Calibrations with pure standards (purchased from Sigma-Aldrich) were carried out for all measured compounds using a Liquid Calibration Unit (Ionicon Analytik GmbH, Innsbruck Austria). For isoprene, the calibration was performed using a standard gas cylinder (Scott Specialty Gases/Air Liquide) containing isoprene $(80.0 \pm 5 \% \mathrm{ppm})$. The isoprene signal was monitored on the ion peaks, corresponding to proton transfer reactions leading to $\mathrm{C}_{5} \mathrm{H}_{9}^{+}$for $\mathrm{H}_{3} \mathrm{O}^{+}$mode and $\mathrm{C}_{5} \mathrm{H}_{8}^{+}$, corresponding to charge transfer reactions, for $\mathrm{NO}^{+}$mode (Karl et al., 2012). The peaks corresponding to the isotopologues were used to monitor the isotopic labelling. Such peaks were ${ }^{13} \mathrm{CC}_{4} \mathrm{H}_{9}^{+}$, ${ }^{13} \mathrm{C}_{2} \mathrm{C}_{3} \mathrm{H}_{9}^{+},{ }^{13} \mathrm{C}_{3} \mathrm{C}_{2} \mathrm{H}_{9}^{+},{ }^{13} \mathrm{C}_{4} \mathrm{CH}_{9}^{+}$, and ${ }^{13} \mathrm{C}_{5} \mathrm{H}_{9}^{+}$for $\mathrm{H}_{3} \mathrm{O}^{+}$ mode and ${ }^{13} \mathrm{CC}_{4} \mathrm{H}_{8}^{+},{ }^{13} \mathrm{C}_{2} \mathrm{C}_{3} \mathrm{H}_{8}^{+},{ }^{13} \mathrm{C}_{3} \mathrm{C}_{2} \mathrm{H}_{8}^{+},{ }^{13} \mathrm{C}_{4} \mathrm{CH}_{8}^{+}$, and ${ }^{13} \mathrm{C}_{5} \mathrm{H}_{8}^{+}$for $\mathrm{NO}^{+}$mode. Ketones undergo proton transfer reactions in $\mathrm{H}_{3} \mathrm{O}^{+}$mode and three body association reactions in $\mathrm{NO}^{+}$mode. This was the case for MVK and MEK, leading to the ion signals $\mathrm{C}_{4} \mathrm{H}_{7} \mathrm{O}^{+}$and $\mathrm{C}_{4} \mathrm{H}_{9} \mathrm{O}^{+}$, respectively, in $\mathrm{H}_{3} \mathrm{O}^{+}$mode and $\mathrm{C}_{4} \mathrm{H}_{6} \mathrm{O} \cdot \mathrm{NO}^{+}$and $\mathrm{C}_{4} \mathrm{H}_{8} \mathrm{O} \cdot \mathrm{NO}^{+}$, respectively, in $\mathrm{NO}^{+}$mode. Aldehydes react at collision rates via proton transfer in $\mathrm{H}_{3} \mathrm{O}^{+}$mode and mainly hydride ion transfer in $\mathrm{NO}^{+}$. In $\mathrm{NO}^{+}$mode aldehydes also undergo three body association reactions at a much reduced rate (Liu et al., 2013). This is the case of MACR and isobutyraldehyde, mostly leading to the ion signals $\mathrm{C}_{4} \mathrm{H}_{7} \mathrm{O}^{+}$and $\mathrm{C}_{4} \mathrm{H}_{9} \mathrm{O}^{+}$, respectively, in $\mathrm{H}_{3} \mathrm{O}^{+}$mode and $\mathrm{C}_{4} \mathrm{H}_{5} \mathrm{O}^{+}$and $\mathrm{C}_{4} \mathrm{H}_{7} \mathrm{O}^{+}$, respectively, in $\mathrm{NO}^{+}$mode. Alcohols typically undergo proton transfer followed by dehydration in $\mathrm{H}_{3} \mathrm{O}^{+}$mode and hydride ion transfer in $\mathrm{NO}^{+}$mode. Details on the spectral peaks used to monitor each compound in red oak are reported in the Table S2. Isotopic labelling was monitored using the signal corresponding to isotopologues analogously to the case of isoprene. Photosynthesis and dark respiration were measured as $\mathrm{CO}_{2}$ exchange. The exchange of $\mathrm{CO}_{2}$ and ${ }^{13} \mathrm{CO}_{2}$ was estimated in $\mathrm{H}_{3} \mathrm{O}^{+}$mode using the spectral peaks at $m / z=44.9971$ and 46.0005, respectively. Since $\mathrm{CO}_{2}$ does not react with $\mathrm{H}_{3} \mathrm{O}^{+}$at collision rate, extensive calibrations with $\mathrm{CO}_{2}$ and ${ }^{13} \mathrm{CO}_{2}$ standards were made at the experimental conditions (Fig. S2). The conditions in the instrument reaction cell were the following: $2.19 \mathrm{mbar}$ drift pressure, $60{ }^{\circ} \mathrm{C}$ drift tube temperature, and $542 \mathrm{~V}$ drift voltage for the $\mathrm{H}_{3} \mathrm{O}^{+}$mode, resulting in an $E / N$ ratio of ca. 125 Townsend (Td) ( $N$ corresponding to the gas number density and $E$ to the electric field strength; $1 \mathrm{Td}=10^{-17} \mathrm{Vcm}^{2}$ ); $2.21 \mathrm{mbar}$ drift pressure, $90^{\circ} \mathrm{C}$ drift tube temperature, and $296 \mathrm{~V}$ drift voltage in $\mathrm{NO}^{+}$mode, resulting in an $E / N$ ratio of ca. $74 \mathrm{Td}$. The purity of the primary ions was high. In $\mathrm{H}_{3} \mathrm{O}^{+}$mode the fractions of spurious $\mathrm{NO}^{+}$and $\mathrm{O}_{2}^{+}$ions were $<0.3 \%$ and $<2.1 \%$, respectively. The amount of primary ions was $3.1 \times 10^{6} \mathrm{cps}$ (counts per second) and the signal of the first water cluster was about $11 \%$. In $\mathrm{NO}^{+}$mode the fractions of spurious $\mathrm{NO}_{2}^{+}, \mathrm{O}_{2}^{+}$, and $\mathrm{H}_{3} \mathrm{O}^{+}$were $<3.5 \%,<0.2 \%$, and $<0.1 \%$ respectively, relative to the primary $\mathrm{NO}^{+}$ion signal. The amount of primary ions was $2.6 \times 10^{6} \mathrm{cps}$. The ion detector in PTR/SRI-ToF-MS was a time-of-fight mass anal-

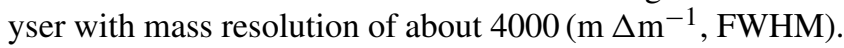
The sampling time per bin of ToF acquisition was $0.1 \mathrm{~ns}$, amounting to 350000 bins for a $\mathrm{m} / \mathrm{z}$ spectrum ranging up to $m / z=400$. The spectral ion signals used to derive VOC concentrations were calculated following the procedure described by Cappellin et al. (2011b). The detector dead time was corrected for applying a procedure based on the Poisson statistics (Cappellin et al., 2011a; Titzmann et al., 2010). Internal mass calibration was applied by achieving a mass accuracy better than $0.001 \mathrm{Th}\left(1 \mathrm{Th}=\mathrm{Da} \mathrm{e}^{-1}\right)($ Cappellin et al., 2010). The extraction of ion counts was performed according to Cappellin et al. (2011b), employing an optimized peak shape from the sample spectra for fitting.

\subsection{Statistics}

Statistical analyses were performed using R routines (R Development Core Team, 2009) developed in-house. Statistical differences of emissions or uptakes in different conditions were assessed using Kruskal-Wallis test at a significance level of $p<0.05$.

Data availability. The dataset is available from https://doi.org/10.4121/uuid:63039e2e-03d6-455d-81dee94c9671f21c (Cappellin, 2019).

Supplement. The supplement related to this article is available online at: https://doi.org/10.5194/acp-19-3125-2019-supplement. 
Author contributions. LC, FL, and KM designed this research. Laboratory analyses were performed by LC, LC, FL, FB, and PP, and $\mathrm{KM}$ wrote the paper.

Competing interests. The authors declare that they have no conflict of interest.

Acknowledgements. Luca Cappellin acknowledges funding from H2020-EU.1.3.2 (grant agreement no. 659315).

Edited by: Thomas Karl

Reviewed by: two anonymous referees

\section{References}

Affek, H. P. and Yakir, D.: Protection by Isoprene against Singlet Oxygen in Leaves, Plant Physiol., 129, 269-277, https://doi.org/10.1104/pp.010909, 2002.

Affek, H. P. and Yakir, D.: Natural Abundance Carbon Isotope Composition of Isoprene Reflects Incomplete Coupling between Isoprene Synthesis and Photosynthetic Carbon Flow, Plant Physiol., 131, 1727-1736, https://doi.org/10.1104/pp.102.012294, 2003.

Alméras, E., Stolz, S., Vollenweider, S., Reymond, P., MèneSaffrané, L., and Farmer, E. E.: Reactive electrophile species activate defense gene expression in Arabidopsis, Plant J., 34, 205216, https://doi.org/10.1046/j.1365-313X.2003.01718.x, 2003.

Andreae, M. O., Artaxo, P., Brandão, C., Carswell, F. E., Ciccioli, P., da Costa, A. L., Culf, A. D., Esteves, J. L., Gash, J. H. C., Grace, J., Kabat, P., Lelieveld, J., Malhi, Y., Manzi, A. O., Meixner, F. X., Nobre, A. D., Nobre, C., Ruivo, M. D. L. P., Silva-Dias, M. A., Stefani, P., Valentini, R., von Jouanne, J., and Waterloo, M. J.: Biogeochemical cycling of carbon, water, energy, trace gases, and aerosols in Amazonia: The LBAEUSTACH experiments, J. Geophys. Res.-Atmos., 107, 8066, https://doi.org/10.1029/2001JD000524, 2002.

Behnke, K., Ehlting, B., Teuber, M., Bauerfeind, M., Louis, S., Hänsch, R., Polle, A., Bohlmann, J., and Schnitzler, J.-P.: Transgenic, non-isoprene emitting poplars don't like it hot, Plant J., 51, 485499, https://doi.org/10.1111/j.1365-313X.2007.03157.x, 2007.

Brilli, F., Barta, C., Fortunati, A., Lerdau, M., Loreto, F., and Centritto, M.: Response of isoprene emission and carbon metabolism to drought in white poplar (Populus alba) saplings, New Phytol., 175, 244-254, https://doi.org/10.1111/j.14698137.2007.02094.x, 2007.

Brilli, F., Ruuskanen, T. M., Schnitzhofer, R., Müller, M., Breitenlechner, M., Bittner, V., Wohlfahrt, G., Loreto, F., and Hansel, A.: Detection of Plant Volatiles after Leaf Wounding and Darkening by Proton Transfer Reaction "Time-ofFlight” Mass Spectrometry (PTR-TOF), PLoS ONE, 6, e20419, https://doi.org/10.1371/journal.pone.0020419, 2011.

Brilli, F., Gioli, B., Fares, S., Terenzio, Z., Zona, D., Gielen, B., Loreto, F., Janssens, I. A., and Ceulemans, R.: Rapid leaf development drives the seasonal pattern of volatile organic compound (VOC) fluxes in a "coppiced" bioenergy poplar plantation, Plant
Cell Environ., 39, 539-555, https://doi.org/10.1111/pce.12638, 2016.

Cappellin, L.: Mechanism for biogenic MEK origin from MVK, https://doi.org/10.4121/uuid:63039e2e-03d6-455d-81dee94c9671f21c, 2019.

Cappellin, L., Biasioli, F., Fabris, A., Schuhfried, E., Soukoulis, C., Mark, T., and Gasperi, F.: Improved mass accuracy in PTR-TOF-MS: Another step towards better compound identification in PTR-MS, Int. J. Mass Spectrom., 290, 60-63, https://doi.org/10.1016/j.ijms.2009.11.007, 2010.

Cappellin, L., Biasioli, F., Schuhfried, E., Soukoulis, C., Märk, T. D., and Gasperi, F.: Extending the dynamic range of proton transfer reaction time-of-flight mass spectrometers by a novel dead time correction, Rapid Commun. Mass Spectrom. RCM, 25, 179-183, https://doi.org/10.1002/rcm.4819, 2011a.

Cappellin, L., Biasioli, F., Granitto, P. M., Schuhfried, E., Soukoulis, C., Costa, F., Märk, T. D., and Gasperi, F.: On data analysis in PTR-TOF-MS: From raw spectra to data mining, Sens. Actuators B Chem., 155, 183-190, https://doi.org/10.1016/j.snb.2010.11.044, 2011b.

Cappellin, L., Algarra Alarcon, A., Herdlinger-Blatt, I., Sanchez, J., Biasioli, F., Martin, S. T., Loreto, F., and McKinney, K. A.: Field observations of volatile organic compound (VOC) exchange in red oaks, Atmos. Chem. Phys., 17, 4189-4207, https://doi.org/10.5194/acp-17-4189-2017, 2017.

Chew, A. A. and Atkinson, R.: $\mathrm{OH}$ radical formation yields from the gas-phase reactions of $\mathrm{O}_{3}$ with alkenes and monoterpenes, J. Geophys. Res.-Atmos., 101, 28649-28653, https://doi.org/10.1029/96JD02722, 1996.

Delfine, S., Di Marco, G., and Loreto, F.: Estimation of photorespiratory carbon dioxide recycling during photosynthesis, Aust J. Plant Physiol., 26, 733-736, https://doi.org/10.1071/PP99096, 1999.

Delledonne, M., Zeier, J., Marocco, A., and Lamb, C.: Signal interactions between nitric oxide and reactive oxygen intermediates in the plant hypersensitive disease resistance response, P. Natl. Acad. Sci. USA, 98, 13454-13459, https://doi.org/10.1073/pnas.231178298, 2001.

Delwiche, C. F. and Sharkey, T. D.: Rapid appearance of ${ }^{13} \mathrm{C}$ in biogenic isoprene when ${ }^{13} \mathrm{CO}_{2}$ is fed to intact leaves, Plant Cell Environ., 16, 587-591, https://doi.org/10.1111/j.13653040.1993.tb00907.x, 1993.

Feng, Y., Wen, S., Chen, Y., Wang, X., Lü, H., Bi, X., Sheng, G., and Fu, J.: Ambient levels of carbonyl compounds and their sources in Guangzhou, China, Atmos. Environ., 39, 1789-1800, https://doi.org/10.1016/j.atmosenv.2004.10.009, 2005.

de Gouw, J., Warneke, C., Karl, T., Eerdekens, G., van der Veen, C., and Fall, R.: Sensitivity and specificity of atmospheric trace gas detection by proton-transfer-reaction mass spectrometry, Int. J. Mass Spectrom., 223, 365-382, 2003.

Grosjean, E., Grosjean, D., Fraser, M. P., and Cass, G. R.: Air Quality Model Evaluation Data for Organics. 2. C1-C14 Carbonyls in Los Angeles Air, Environ. Sci. Technol., 30, 2687 2703, https://doi.org/10.1021/es950758w, 1996.

Harrison, S. P., Morfopoulos, C., Dani, K. G. S., Prentice, I. C., Arneth, A., Atwell, B. J., Barkley, M. P., Leishman, M. R., Loreto, F., Medlyn, B. E., Niinemets, Ü., Possell, M., Peñuelas, J., and Wright, I. J.: Volatile isoprenoid emissions from plastid to planet, 
New Phytol., 197,, 49-57, https://doi.org/10.1111/nph.12021, 2013.

Harvey, C. M. and Sharkey, T. D.: Exogenous isoprene modulates gene expression in unstressed Arabidopsis thaliana plants, Plant Cell Environ., 39, 1251-1263, https://doi.org/10.1111/pce.12660, 2016.

Harvey, C. M., Li, Z., Tjellström, H., Blanchard, G. J., and Sharkey, T. D.: Concentration of isoprene in artificial and thylakoid membranes, J. Bioenerg. Biomembr., 47, 419-429, https://doi.org/10.1007/s10863-015-9625-9, 2015.

Jardine, K., Abrell, L., Kurc, S. A., Huxman, T., Ortega, J., and Guenther, A.: Volatile organic compound emissions from Larrea tridentata (creosotebush), Atmos. Chem. Phys., 10, 1219112206, https://doi.org/10.5194/acp-10-12191-2010, 2010.

Jardine, K., Chambers, J., Alves, E. G., Teixeira, A., Garcia, S., Holm, J., Higuchi, N., Manzi, A., Abrell, L., Fuentes, J. D., Nielsen, L. K., Torn, M. S., and Vickers, C. E.: Dynamic Balancing of Isoprene Carbon Sources Reflects Photosynthetic and Photorespiratory Responses to Temperature Stress, PLANT Physiol., 166, 2051-2064, https://doi.org/10.1104/pp.114.247494, 2014.

Jardine, K. J., Monson, R. K., Abrell, L., Saleska, S. R., Arneth, A., Jardine, A., Ishida, F. Y., Serrano, A. M. Y., Artaxo, P., Karl, T., Fares, S., Goldstein, A., Loreto, F., and Huxman, T.: Within-plant isoprene oxidation confirmed by direct emissions of oxidation products methyl vinyl ketone and methacrolein, Global Change Biol., 18, 973-984, https://doi.org/10.1111/j.1365-2486.2011.02610.x, 2012.

Jardine, K. J., Meyers, K., Abrell, L., Alves, E. G., Yanez Serrano, A. M., Kesselmeier, J., Karl, T., Guenther, A., Vickers, C., and Chambers, J. Q.: Emissions of putative isoprene oxidation products from mango branches under abiotic stress, J. Exp. Bot., 64, 3669-3679, https://doi.org/10.1093/jxb/ert202, 2013.

Jenkin, M. E., Saunders, S. M., and Pilling, M. J.: The tropospheric degradation of volatile organic compounds: a protocol for mechanism development, Atmos. Environ., 31, 81-104, https://doi.org/10.1016/S1352-2310(96)00105-7, 1997.

Jordan, A., Haidacher, S., Hanel, G., Hartungen, E., Herbig, J., Märk, L., Schottkowsky, R., Seehauser, H., Sulzer, P., and Märk, T. D.: An online ultra-high sensitivity Proton-transfer-reaction mass-spectrometer combined with switchable reagent ion capability (PTR + SRI - MS), Int. J. Mass Spectrom., 286, 32-38, https://doi.org/10.1016/j.ijms.2009.06.006, 2009.

Kai, H., Hirashima, K., Matsuda, O., Ikegami, H., Winkelmann, T., Nakahara, T., and Iba, K.: Thermotolerant cyclamen with reduced acrolein and methyl vinyl ketone, J. Exp. Bot., 63, 41434150, https://doi.org/10.1093/jxb/ers110, 2012.

Karl, T., Potosnak, M., Guenther, A., Clark, D., Walker, J., Herrick, J. D., and Geron, C.: Exchange processes of volatile organic compounds above a tropical rain forest: Implications for modeling tropospheric chemistry above dense vegetation, J. Geophys. Res.-Atmos., 109, D18306, https://doi.org/10.1029/2004JD004738, 2004.

Karl, T., Harley, P., Guenther, A., Rasmussen, R., Baker, B., Jardine, K., and Nemitz, E.: The bi-directional exchange of oxygenated VOCs between a loblolly pine (Pinus taeda) plantation and the atmosphere, Atmos. Chem. Phys., 5, 3015-3031, https://doi.org/10.5194/acp-5-3015-2005, 2005.

Karl, T., Harley, P., Emmons, L., Thornton, B., Guenther, A., Basu, C., Turnipseed, A., and Jardine, K.: Efficient Atmospheric
Cleansing of Oxidized Organic Trace Gases by Vegetation, Science, 330, 816-819, https://doi.org/10.1126/science.1192534, 2010.

Karl, T., Hansel, A., Cappellin, L., Kaser, L., HerdlingerBlatt, I., and Jud, W.: Selective measurements of isoprene and 2-methyl-3-buten-2-ol based on $\mathrm{NO}+$ ionization mass spectrometry, Atmos. Chem. Phys., 12, 11877-11884, https://doi.org/10.5194/acp-12-11877-2012, 2012.

Kergomard, A., Renard, M. F., Veschambre, H., Courtois, D., and Petiard, V.: Reduction of $\alpha, \beta$-unsaturated ketones by plant suspension cultures, Phytochemistry, 27, 407-409, https://doi.org/10.1016/0031-9422(88)83108-X, 1988.

Knudsen, J. T., Tollsten, L., and Bergström, L. G.: Floral scents - a checklist of volatile compounds isolated by head-space techniques, Phytochemistry, 33, 253-280, https://doi.org/10.1016/0031-9422(93)85502-I, 1993.

Legreid, G., Lööv, J. B., Staehelin, J., Hueglin, C., Hill, M., Buchmann, B., Prevot, A. S. H., and Reimann, S.: Oxygenated volatile organic compounds (OVOCs) at an urban background site in Zürich (Europe): Seasonal variation and source allocation, Atmos. Environ., 41, 8409-8423, https://doi.org/10.1016/j.atmosenv.2007.07.026, 2007.

Liu, Y. J., Herdlinger-Blatt, I., McKinney, K. A., and Martin, S. T.: Production of methyl vinyl ketone and methacrolein via the hydroperoxyl pathway of isoprene oxidation, Atmos. Chem. Phys., 13, 5715-5730, https://doi.org/10.5194/acp-135715-2013, 2013.

Loivamäki, M., Gilmer, F., Fischbach, R. J., Sörgel, C., Bachl, A., Walter, A., and Schnitzler, J.-P.: Arabidopsis, a Model to Study Biological Functions of Isoprene Emission?, Plant Physiol., 144, 1066-1078, https://doi.org/10.1104/pp.107.098509, 2007.

Loreto, F.: 13C Labeling Reveals Chloroplastic and Extrachloroplastic Pools of Dimethylallyl Pyrophosphate and Their Contribution to Isoprene Formation, PLANT Physiol., 135, 1903-1907, https://doi.org/10.1104/pp.104.039537, 2004.

Loreto, F. and Schnitzler, J.-P.: Abiotic stresses and induced BVOCs, Trends Plant Sci., 15, 154-166, https://doi.org/10.1016/j.tplants.2009.12.006, 2010.

Loreto, F. and Sharkey, T. D.: A gas-exchange study of photosynthesis and isoprene emission inQuercus rubra, Planta, 182, 523-531, https://doi.org/10.1007/BF02341027, 1990.

Loreto, F. and Velikova, V.: Isoprene Produced by Leaves Protects the Photosynthetic Apparatus against Ozone Damage, Quenches Ozone Products, and Reduces Lipid Peroxidation of Cellular Membranes, PLANT Physiol., 127, 1781-1787, https://doi.org/10.1104/pp.010497, 2001.

Loreto, F., Centritto, M., Barta, C., Calfapietra, C., Fares, S., and Monson, R. K.: The relationship between isoprene emission rate and dark respiration rate in white poplar (Populus alba L.) leaves, Plant Cell Environ., 30, 662-669, https://doi.org/10.1111/j.13653040.2007.01648.x, 2007.

Mittler, R., Vanderauwera, S., Suzuki, N., Miller, G., Tognetti, V. B., Vandepoele, K., Gollery, M., Shulaev, V., and Van Breusegem, F.: ROS signaling: the new wave?, Trends Plant Sci., 16, 300-309, https://doi.org/10.1016/j.tplants.2011.03.007, 2011.

Moore, D. P., Remedios, J. J., and Waterfall, A. M.: Global distributions of acetone in the upper troposphere from MIPAS spectra, Atmos. Chem. Phys., 12, 757-768, https://doi.org/10.5194/acp12-757-2012, 2012. 
Muramoto, S., Matsubara, Y., Mwenda, C. M., Koeduka, T., Sakami, T., Tani, A., and Matsui, K.: Glutathionylation and Reduction of Methacrolein in Tomato Plants Account for Its Absorption from the Vapor Phase, Plant Physiol., 169, 1744-1754, https://doi.org/10.1104/pp.15.01045, 2015.

Niinemets, Ü., Loreto, F., and Reichstein, M.: Physiological and physicochemical controls on foliar volatile organic compound emissions, Trends Plant Sci., 9, 180-186, https://doi.org/10.1016/j.tplants.2004.02.006, 2004.

Nölscher, A. C., Yañez-Serrano, A. M., Wolff, S., de Araujo, A. C., Lavrič, J. V., Kesselmeier, J., and Williams, J.: Unexpected seasonality in quantity and composition of Amazon rainforest air reactivity, Nat. Commun., 7, 10383, https://doi.org/10.1038/ncomms10383, 2016.

Oikawa, P. Y. and Lerdau, M. T.: Catabolism of volatile organic compounds influences plant survival, Trends Plant Sci., 18, 695703, https://doi.org/10.1016/j.tplants.2013.08.011, 2013.

Omasa, K., Tobe, K., Hosomi, M., and Kobayashi, M.: Absorption of Ozone and Seven Organic Pollutants by Populus nigra and Camellia sasanqua, Environ. Sci. Technol., 34, 2498-2500, https://doi.org/10.1021/es991285m, 2000.

Pollastri, S., Tsonev, T., and Loreto, F.: Isoprene improves photochemical efficiency and enhances heat dissipation in plants at physiological temperatures, J. Exp. Bot., 65, 1565-1570, https://doi.org/10.1093/jxb/eru033, 2014.

R Development Core Team: R: A Language and Environment for Statistical Computing, Vienna, Austria, available at: http://www. R-project.org (last access: 20 August 2018), 2009.

Sasaki, K., Saito, T., Lämsä, M., Oksman-Caldentey, K.-M., Suzuki, M., Ohyama, K., Muranaka, T., Ohara, K., and Yazaki, K.: Plants Utilize Isoprene Emission as a Thermotolerance Mechanism, Plant Cell Physiol., 48, 1254-1262, https://doi.org/10.1093/pcp/pcm104, 2007.

Sharkey, T. D., Yeh, S., Wiberley, A. E., Falbel, T. G., Gong, D., and Fernandez, D. E.: Evolution of the Isoprene Biosynthetic Pathway in Kudzu, Plant Physiol., 137, 700-712, https://doi.org/10.1104/pp.104.054445, 2005.

Sin, D. W. M., Wong, Y.-C., and Louie, P. K. K.: Trends of ambient carbonyl compounds in the urban environment of Hong Kong, Atmos. Environ., 35, 5961-5969, https://doi.org/10.1016/S13522310(01)00359-4, 2001

Singh, H. B., Salas, L. J., Chatfield, R. B., Czech, E., Fried, A., Walega, J., Evans, M. J., Field, B. D., Jacob, D. J., Blake, D., Heikes, B., Talbot, R., Sachse, G., Crawford, J. H., Avery, M. A., Sandholm, S., and Fuelberg, H.: Analysis of the atmospheric distribution, sources, and sinks of oxygenated volatile organic chemicals based on measurements over the Pacific during TRACE-P, J. Geophys. Res., 109, D15S07, https://doi.org/10.1029/2003JD003883, 2004.

Sommariva, R., de Gouw, J. A., Trainer, M., Atlas, E., Goldan, P. D., Kuster, W. C., Warneke, C., and Fehsenfeld, F. C.: Emissions and photochemistry of oxygenated VOCs in urban plumes in the Northeastern United States, Atmos. Chem. Phys., 11, 70817096, https://doi.org/10.5194/acp-11-7081-2011, 2011.

Tani, A. and Hewitt, C. N.: Uptake of Aldehydes and Ketones at Typical Indoor Concentrations by Houseplants, Environ. Sci. Technol., 43, 8338-8343, https://doi.org/10.1021/es9020316, 2009.
Tani, A., Tobe, S., and Shimizu, S.: Uptake of Methacrolein and Methyl Vinyl Ketone by Tree Saplings and Implications for Forest Atmosphere, Environ. Sci. Technol., 44, 7096-7101, https://doi.org/10.1021/es1017569, 2010.

Tani, A., Tobe, S., and Shimizu, S.: Leaf uptake of methyl ethyl ketone and croton aldehyde by Castanopsis sieboldii and Viburnum odoratissimum saplings, Atmos. Environ., 70, 300-306, https://doi.org/10.1016/j.atmosenv.2012.12.043, 2013.

Tattini, M., Loreto, F., Fini, A., Guidi, L., Brunetti, C., Velikova, V., Gori, A., and Ferrini, F.: Isoprenoids and phenylpropanoids are part of the antioxidant defense orchestrated daily by drought-stressed Platanus $\times$ acerifolia plants during Mediterranean summers, New Phytol., 207, 613-626, https://doi.org/10.1111/nph.13380, 2015.

Titzmann, T., Graus, M., Müller, M., Hansel, A., and Ostermann, A.: Improved peak analysis of signals based on counting systems: Illustrated for proton-transfer-reaction time-offlight mass spectrometry, Int. J. Mass Spectrom., 295, 72-77, https://doi.org/10.1016/j.ijms.2010.07.009, 2010.

Velikova, V., Varkonyi, Z., Szabo, M., Maslenkova, L., Nogues, I., Kovacs, L., Peeva, V., Busheva, M., Garab, G., Sharkey, T. D., and Loreto, F.: Increased Thermostability of Thylakoid Membranes in Isoprene-Emitting Leaves Probed with Three Biophysical Techniques, Plant Physiol., 157, 905-916, https://doi.org/10.1104/pp.111.182519, 2011.

Vickers, C. E., Possell, M., Cojocariu, C. I., Velikova, V. B., Laothawornkitkul, J., Ryan, A., Mullineaux, P. M., and Nicholas Hewitt, C.: Isoprene synthesis protects transgenic tobacco plants from oxidative stress, Plant Cell Environ., 32, 520-531, https://doi.org/10.1111/j.1365-3040.2009.01946.x, 2009.

Vickers, C. E., Possell, M., Laothawornkitkul, J., Ryan, A. C., Hewitt, C. N., and Mullineaux, P. M.: Isoprene synthesis in plants: lessons from a transgenic tobacco model, Plant Cell Environ., 34, 1043-1053, https://doi.org/10.1111/j.13653040.2011.02303.x, 2011.

Vollenweider, S., Weber, H., Stolz, S., Chételat, A., and Farmer, E. E.: Fatty acid ketodienes and fatty acid ketotrienes: Michael addition acceptors that accumulate in wounded and diseased Arabidopsis leaves, Plant J., 24, 467-476, https://doi.org/10.1111/j.1365-313X.2000.00897.x, 2000.

Yáñez-Serrano, A. M., Nölscher, A. C., Williams, J., Wolff, S., Alves, E., Martins, G. A., Bourtsoukidis, E., Brito, J., Jardine, K., Artaxo, P., and Kesselmeier, J.: Diel and seasonal changes of biogenic volatile organic compounds within and above an Amazonian rainforest, Atmos. Chem. Phys., 15, 3359-3378, https://doi.org/10.5194/acp-15-3359-2015, 2015.

Yáñez-Serrano, A. M., Nölscher, A. C., Bourtsoukidis, E., Derstroff, B., Zannoni, N., Gros, V., Lanza, M., Brito, J., Noe, S. M., House, E., Hewitt, C. N., Langford, B., Nemitz, E., Behrendt, T., Williams, J., Artaxo, P., Andreae, M. O., and Kesselmeier, J.: Atmospheric mixing ratios of methyl ethyl ketone (2-butanone) in tropical, boreal, temperate and marine environments, Atmos. Chem. Phys., 16, 10965-10984, https://doi.org/10.5194/acp-1610965-2016, 2016. 